\title{
Role of Unani Medicine in the Prevention and Management of Substance Abuse
}

\section{Quddusi N*, Nighat Anjum², Usama Akram ${ }^{3}$ and Fazil M ${ }^{4}$}

${ }^{1}$ Research Officer, Scientist-III, Hakim Ajmal Khan Institute for Literary and Historical Research in Unani Medicine, (CCRUM), New Delhi, India

${ }^{2}$ Research Officer, Scientist-III Central Council for Research in Unani Medicine, (CCRUM),Headquarters New Delhi, India

${ }^{3}$ Research Officer, Hakim Ajmal Khan Institute for Literary and Historical Research in Unani Medicine, (CCRUM), New Delhi, India

${ }^{4}$ Assitant Director (Incharge), Hakim Ajmal Khan Institute for Literary and Historical

Research in Unani Medicine, (CCRUM), New Delhi, India

*Corresponding Author: Quddusi N, Research Officer, Scientist-III, Hakim Ajmal

Khan Institute for Literary and Historical Research in Unani Medicine, (CCRUM),

New Delhi, India.

DOI: $10.31080 /$ ASMS.2020.04.0564
Received: February 03, 2020

Published: February 11, 2020

(C) All rights are reserved by Quddusi N., et al.

\begin{abstract}
Substances that can cure a disease are known as drugs. This is a very broad term. This word not only includes those substances that cure the diseases but also include drugs like cocaine, heroine, tobacco and other such medicines that when consumed, alter our mood or functioning. Substance abuse or drug abuse is the deliberate use of a substance in a manner that damages the health or ability to function and in the long run leads to addiction i.e use of substance in a chronic, compulsive or uncontrollable way [1]. This addiction or dependence cannot be easily give up or stopped. The Unani System of Medicine has got an immense potential in the field of De- addiction and Rehabilitation. The System not only takes care of withdrawal management but also supports psycho social behavior/ailments [5]. Apart from drug therapy, there are basic principle of leading a normal life, Asbabi Sitta Zaruriyai. e six essential factors of life in Unani medicine. By following these factors, one can easily prevent the substance abuse [6].
\end{abstract}

Keywords: Unani; Substance Abuse

\section{Introduction}

Substance abuse can simply be defined as a pattern of harmful use of any substance for mood-altering purposes. "Substances" can include alcohol and other drugs (illegal or not) as well as some substances that are not drugs at all. Among these other drugs there are stimulants that increase the level of activity in one or more parts of Central Nervous System. These include cocaine, nicotine, caffeine, amphetamines etc. these drugs usually elevate mood, increase alertness and reduce fatigue. in higher doses, they produce irritability, anxiety and psychotic pattern of behavior. Caffeine is the component of popular beverages and most commonly used stimulant [1].

Another group of drugs that come under substance abuse are the depressants that also act on nervous system but exactly opposite of stimulants. These are also known as sedatives, hypnotics and are generally used in the management of sleep disorders and anxiety. Widely used depressant is alcohol. Physical and psychological dependence and alcohol abuse results in health risks including liver damage, increased risk of cancer and premature death. 
Anaesthetics are those drugs that produce an artificial loss of sensation in order to relieve pain [1].

\section{Prevalence}

Substance abuse and addiction are a major burden and a burning problem for Indian society which creates a social and economic crisis as people from various status of the society are becoming victims of this abuse day-by day. As per the National Survey on Extent, Pattern and Trends of Drug abuse in India conducted by the Centre in collaboration with United Nations Office on Drugs and Crime in 2004, the current prevalence rates within the age group of 12 - 18 years was Alcohol (21.4\%), Cannabis (3\%), Opiates $(0.7 \%)$ and any illicit drug (3.6\%). It is estimated that there are about 6.25 crore alcoholics, 90 lakh Cannabis and 2.5 lakhs opiates and nearly 10 lakh illicit drug users in the country [2]. The first drug used to treat psychosis was reserpine, made from a plant called rauwolfia in India and had been used for centuries [3]. In recent years, prescription drug abuse has become an escalating problem, most commonly involving opioid painkillers, anti-anxiety medications, sedatives, and stimulants [3].

\section{Opioid drug abuse}

These drugs are generally used as prescribed painkillers. Many people start taking these drugs to cope with a specific medical problem for example taking painkillers following injury or surgery However, over time, increased doses are needed to achieve the same level of pain relief and people start abusing medication not prescribed for them in order to experience a high, relieve tension, increase alertness, or improve concentration and some users can become physically dependent, experiencing withdrawal symptoms such as Nausea, Muscle cramping, Depression, Agitation, Anxiety, Opiate cravings, if they try to quit. Signs of opioid drug abuse are drooping eyes, constricted pupils even in dim light, sudden itching or flushing, slurred speech; drowsiness, lack of energy; inability to concentrate, lack of motivation, decline in performance at work or school; neglecting friendships and social activities [4].

Unani system of medicine and substance abuse

The Unani System of Medicine has got an immense potential in the field of De- addiction and Rehabilitation. The System not only takes care of withdrawal management but also supports psycho social behavior/ailments. In Unani System of Medicine the concept of Ilaj Nafsani (Psychiatric treatment) is very unique. This treatment involves the treatment of psychiatric diseases either by the using drugs or by modifications in the Six Essential Factors of Life
(Asbab Sitta Zaruriya). Apart from this, Ilaj Ruhani(Spiritual Treatment) also helps in treating psychiatric and drug abuse related disorders e.g. meditation. This System is equipped with traditional therapeutic and interventional therapies, such as, IlajbilTadbeer (Regimen Therapy), Consultation, Meditation, which can be used in making diagnosis anddetoxification from drugs abuse. This System also provides psychosocial intervention for the management of Substance abuse.

There are a number of substances or drugs in Unani System, if used without the advice of physician can lead to dependency. All these drugs are included in substance abuse or drug abuse. These are as follows:

- Mukhaddirat (Anaesthetic drugs) e.g Dhatura (Datura stramonium Linn.), Beesh (Aconitum napellus Linn.), Bhang (Cannabis sativa Linn.), Afiyun (Papaver somniferum Linn.), Ajwain Khurasani (Hyoscyamus alba), Luffah (AtropaacuminataRoyle ex Lindl.), Shokran (Conium maculatum Linn.),etc [5,6].

- Munawwimat(Sedative/Hypnotic drugs) e. g Afiyun ( $P a-$ paver somniferum Linn.), Dhatura (Datura stramonium Linn.), Post Khashkhash (Papaver somniferum Linn.), etc $[5,6]$.

- Musakkirat (drugs that divert the gases towards the brain thereby disturbing the normal functioning of the brain) e.gBhang (Cannabis sativa Linn.), Sharaab (alcohol) [5,6].

\section{Management of substance abuse in unani medicine}

For the management of drugs abuse, Unani System has Musakkinat (Calming Drugs). These are the drugs that create calmness in nervous system but do not cause stimulation in any phase and do not create dependency. Apart from these drugs there are $\mathrm{Mu}$ farrihat (Exhilirant drugs) that help in mood elevation, e.g. Abresham (Silk Cocoon), Ilaichi (Elettariacardamomum (Linn.) Maton), Balango (Lallemantiaroyleana Benth.), Jawatri (Myristicafragrans Houtt.), Gul e Gaozaban (Onosmabracteatum), Gul e Surkh (Rosa damascena Mill.), Arq Bedmushk (Salix caprea Linn.), Arq Keora (Pandanus tectorius Soland. ex Park.), etc thus help in keeping away from substance abuse [5].

Different compound drugs used in Unani System such as Majun Najah, Majun Nasyan, Majun Khadr jadeedetc also help in management of substance abuse. There is one formulation in the Unani 
classical book i.e Qarabadeeni Azam named as Majun Kuchla specifically mentioned to be best for the treatment and management of Afiyun or Opium dependency. This formulation contains Kuchla Mudabbar (Strychnosnuxvomica Linn.), Gul iGaozaban (Onosmabracteatum), Ilaichi (Elettariacardamomum (Linn.), Zaranbad (Zingiber zerumbet Rosc ex Smith), Shaqaqul (Pastinacasecacul), Sandal Safaid (Santalum album Linn.), Amla (Emblica officinalis Gaertn.), HalelaSiyah (Terminalia chebula Retz.), Ood Hindi (Aquilaria malaccensis Lam.), Ustukhuddoos (Lavandula stoechas Linn.), Kateera, Narjeel (Cocos nucifera Linn.), Maghz Chilghoza (Piper attenuatum), Qaranfal (Syzygiumaromaticum (Linn.) Merr. And L.M. Perry) and honey [7-9]. All these drugs are Mufarreh/ Muqawwii Dimagh/ Musakkin which help in treating and managing opioid dependency.

Another important compound formulation and pharmacopoeia formulation is from another Unani classic, Ilaj al Amraz for opioid de-addiction is Habbi Shifacontaining Dhatura (Datura stramonium Linn.), Zanjbeel (Zingiber officinale Roscoe), Rewand (Rheum officinale Baill.) [9].

The treatment of drug abuse is important to reduce its health and social consequences. Management of Drug addicts involve multi-disciplinary approach i.e. not only to manage withdrawal symptoms, but also to take care of psycho social factors contributing to the problems of drug dependence. For this Unani system provide different compound formulations for strengthening psychic facultyeg. HabbiShifa containing Zanjbeel (Zingiber officinale Roscoe), Jauzbua (MyristicafragransHoutt.), Darchini (Cinnamomumzeylanicum Blume), JauzMaasil (Datura stramonium Linn.) [9].

\section{Prevention of Substance abuse}

- $\quad$ Lead active lives in the family, workplace, and community [4].

- $\quad$ Take prescription medication, after consulting a physician and it's important to take it only as directed, use the lowest dose for the shortest period possible [4].

- Awareness of any signs of dependency can help identify prescription drug problems at an early stage and help to prevent them progressing into an addiction [4].

- Motivation of family and friends [4].

- Use of aromatherapy for prevention of stress and achieving emotional health [4].

\section{Conclusion}

In the light of above information from the Classical text of Unani Medicine, it may be concluded that this System has got a tremendous potential in combating the problem of substance abuse. There are many single and compound Formulations written in Classical text that can help in managing the problems related to substance abuse and withdrawal symptoms. Of these, some of the medicines have been clinically validated and scientically proved and there is a need of further validation studies so that it benefits the suffering population.

\section{Bibliography}

1. Schlaadt RG. Grolier Wellness Encyclopedia, Drugs, Society and Behaviour, Dushkin Publishing group, Guilford, CT 3 (1992): 3.

2. Myanmar opium cultivation drops again as the regional drug economy continues to evolve (2019).

3. Davies DL. "Reserpine in the treatment of anxious and depressed patients". Lancet 266.6881 (1955):117-120.

4. www.addictionandrecovery.org

5. Khan A. Muheet i Azam (Persian), MatbaNizami, Kanpur 1313 55-60.

6. Ghani N. KhazainulAdvia (Urdu), Idaara Kitabushshifa, New Delhi, YNM 55.

7. Khan A. Qarabadini Azam (Persian), CCRUM, New Delhi (2009): 459.

8. Ghani N. QarabadiniNajmulGhani(Urdu), CCRUM, New Delhi (2010): 384.

9. Khan S. Ilaj al Amraz (Persian), Matba'NamiMunshi Naval Kishor, Lucknow (1884): 122.

\section{Assets from publication with us}

- Prompt Acknowledgement after receiving the article

- Thorough Double blinded peer review

- Rapid Publication

- Issue of Publication Certificate

- High visibility of your Published work

Website: https://www.actascientific.com/

Submit Article: https://www.actascientific.com/submission.php Email us: editor@actascientific.com

Contact us: +919182824667 